\title{
Butyrylcholinesterase genetic variability in Guarani Amerindians from the Brazilian state of Mato Grosso do Sul
}

\author{
Lupe Furtado $^{1}$, Ricardo L. R. Souza ${ }^{1}$, Luiza T. Tsuneto ${ }^{2}$, Maria Luiza Petzl-Erler ${ }^{1}$ \\ and Eleidi A. Chautard-Freire-Maia ${ }^{1}$ \\ ${ }^{1}$ Universidade Federal do Paraná, Departamento de Genética, Curitiba, PR, Brazil. \\ ${ }^{2}$ Universidade Estadual de Maringá, Departamento de Análises Clínicas, PR, Brazil.
}

\begin{abstract}
Human butyrylcholinesterase (BChE; EC 3.1.1.8) is a polymorphic enzyme coded by the BCHE gene (3q26.1-q26.2) while the CHE2 gene (2q33-q35) determines a still not characterized substance that forms a complex with BChE $\left(\mathrm{C}_{5}\right)$, being the CHE2 C5+ and CHE2 C5- phenotypes detected in electrophoresis. The present study investigated $B C H E$ and $C H E 2$ variability and the BChE activity of Brazilian Guarani Amerindians from the Kaiowá and Nandeva sub-groups living in several indigenous territories in the Brazilian state of Mato Grosso do Sul. The frequency of the $B C H E$ exon $2 D 70 G(A)$ allele was $0.60 \% \pm 0.35 \%$ while that of the $B C H E$ exon 2 G390V $(F-2)$ allele, never before screened in Amerindians, was $8.82 \% \pm 1.35 \%$. This is the first time that the $B C H E$ gene exon $4 A 539 T(K)$ allele has been surveyed in Brazilian Amerindians where it was found at a frequency of $3.69 \% \pm 0.85 \%$, similar to that found in Chilean Mapuche Amerindians. The BCHE gene variability seen in this survey differs from that of non-isolated populations in respect to both $A 539 T$ and G390V allele frequency. The CHE2 C5+ phenotype frequency was $14.40 \% \pm 2.22 \%$ and falls within the range of that found for other Brazilian Amerindian samples.
\end{abstract}

Key words: $B C H E$ gene, $A$ allele, $F-2$ and $K$ alleles, Guarani-Kaiowá, Guarani-Ñandeva.

Received: December 2, 2004; Accepted: June 8, 2005.

\section{Introduction}

The amino acid sequence of human butyrylcholinesterase (BChE; EC 3.1.1.8) is encoded by the BCHE gene (3q26.1-q26.2). This gene variability is characterized by DNA analysis and some phenotypes are also characterized by enzymatic inhibition tests. The alleles usually detected in population studies are: $U$ (usual; wild-type); $D 70 G$ (atypical or $A$; 70Asp $\rightarrow$ Gly; 209A $\rightarrow$ G); T243M (fluoride resistant $F$-1; 243Thr $\rightarrow$ Met; 728C $\rightarrow$ T); G390V (fluoride resistant $F$-2; 390Gly $\rightarrow$ Val; $1169 \mathrm{G} \rightarrow \mathrm{T})$ and $A 539 T(K$; 539Ala $\rightarrow$ Thr; $1615 \mathrm{G} \rightarrow \mathrm{A})$. The N-terminal aminoacid of the mature BChE protein is Glu 1 with nt 1 corresponding to the first nt in the codon for the Glu 1 (Arpagaus et al., 1990). The genetic variability of BChE also depends on the interaction of the $B C H E$ and $C H E 2$ (2q33-q35) gene products. Two alleles of the $\mathrm{CHE} 2$ gene $(\mathrm{CHE} 2 * \mathrm{C} 5$ - and $\mathrm{CHE} 2{ }^{*} \mathrm{C} 5+$ ) determine the $\mathrm{CHE} 2 \mathrm{C5}-$ and $\mathrm{CHE} 2 \mathrm{C} 5+$ (dominant) phenotypes characterized by the absence and presence of the $\mathrm{C}_{5}$ complex, respectively. This complex is

Send correspondence to Eleidi A. Chautard-Freire-Maia. Universidade Federal do Paraná, Departamento de Genética, Caixa Postal 19071, 81531-990 Curitiba PR, Brazil. E-mail:eleidi@ufpr.br. formed by the $\mathrm{BChE}$ tetramer linked to a still unidentified molecule (Masson, 1991) conditioned by the CHE2 gene.

$\mathrm{BChE}$ variability has been studied in many Brazilian Amerindian groups (review in Alcântara et al., 1995) using both enzyme inhibition tests and electrophoretic methods. It is well-known that, compared to other groups, Amerindians present a restricted number of alleles in many of the genes so far investigated.

During the present study, two Guarani Amerindian sub-groups (Guarani-Kaiowá and Guarani-Ñandeva) from the Brazilian state of Mato Grosso do Sul were investigated for BChE variability, using DNA analysis for the detection of $B C H E$ gene variants. The aim of the present study was to gather additional information on the genetic variability of butyrylcholinesterase in these Amerindians by examining the CHE2 phenotype frequencies and searching for $B C H E$ variants, some of which (e.g. T243M and A539T) having been previously uninvestigated in Brazilian Amerindians. The additional information on the variability of these loci was used for testing two alternatives of the hypothesis related to the origin of each $\mathrm{BChE}$ variant, namely that they were already present in paleo-Amerindians or were introduced due to European gene flow. 


\section{Materials and Methods}

\section{Sample populations}

DNA and plasma were obtained from peripheral blood samples from Brazilian Amerindians of the Guarani-Kaiowá $(\mathrm{N}=150)$ and Guarani-Ñandeva $(\mathrm{N}=84)$ sub-groups along with 22 of both Kaiowá and Ñandeva ancestry. These Amerindians live in 18 municipalities of the Brazilian state of Mato Grosso do Sul, principally the Amambai, Porto Lindo and Limão Verde municipalities but also from the Campanaria, Campestre, Caraapo, Cerrito, Dourados, Guaimbé, Jacaré, Lagoa Bonita, Miranda, Panambi, Pirajuí, Sapucaia, Sossoro, Tacuru, Taquapiri municipalities. All the communities were within an area extending from $20^{\circ} 24^{\prime} \mathrm{S}$ to $23^{\circ} 93^{\prime} \mathrm{S}$ and from $54^{\circ} 58^{\prime} \mathrm{W}$ to $56^{\circ} 55^{\prime} \mathrm{W}$. This study was approved by the "Ethics Committee for Research with Human Beings of the State University of Maringá, Paraná”.

\section{Enzyme inhibition}

Enzyme inhibition tests (Alcântara et al., 1991, as modified by Picheth et al., 1994) were used for the detection of the atypical variant. The phenotype screening of 250 individuals was performed using alpha-naphthyl-acetate as substrate and DL-propranolol as inhibitor. The non-usual phenotypes, as well as those with borderline values, were confirmed using DL-propranolol and Ro2-0683 [dimethylcarbamate of (2-hydroxy-5-phenylbenzyl)-trimethylammonium bromide] as inhibitors.

\section{Enzyme activity}

The method of Dietz et al. (1973) was used to determine BChE activity using propionylthiocholine as substrate at $25^{\circ} \mathrm{C}$.

\section{Phenotypyng of the CHE2 locus}

The CHE2 phenotypes were identified by acid agar gel electrophoresis with subsequent application of alphanaphthyl-acetate as substrate (Van Ros and Vervoort (1973), as modified by Alcântara et al. (2001)). This procedure separates the $\mathrm{C}_{5}$ complex from all other $\mathrm{BChE}$ forms which constitute only one band. The phenotypes were classified as CHE2 C5- when only one band was seen at the negative pole or $\mathrm{CHE} 2 \mathrm{C} 5+$ when one band was seen at the negative pole and another band $\left(\mathrm{C}_{5}\right.$ complex $)$ at the positive pole.

\section{Extraction of DNA and analysis of segments of the $B C H E$ gene}

DNA was extracted from peripheral leukocytes according to the method of Lahiri and Nurnberger (1991) and amplified by PCR (35 cycles with temperatures of $94{ }^{\circ} \mathrm{C}$, $48^{\circ} \mathrm{C}$ and $72^{\circ} \mathrm{C}$ for $1 \mathrm{~min}$ each; final extension at $72^{\circ} \mathrm{C}$ for $10 \mathrm{~min}$ ): $1 \mu \mathrm{L}$ of DNA (about $100 \mathrm{ng}$ ), $19 \mu \mathrm{L}$ of PCR super MIX (Invitrogen) and $10 \mathrm{pmol}$ of each primer. The primers used were N25 and N23, N75 and N73 (Souza et al., 2005), P35 and P33 (Höler et al., 1995), AP5 (Bartels et al. 1992b) and P43 (Höler et al., 1995), for the amplification of DNA sequences containing the $D 70 G$ and $G 390 \mathrm{~V}$ mutation sites (exon 2), exons 3 and 4 (A539T mutation), respectively.

SSCA (Single Strand Conformation Analysis) was used for variant detection. The mixture containing the PCR product $(5 \mu \mathrm{L})$ was added to $6 \mu \mathrm{L}$ of the denaturation solution $(95 \%$ formamide, $0.25 \%$ bromophenol blue, $0.25 \%$ xylene cyanole, $10 \mathrm{mM}$ EDTA and $10 \mathrm{mM} \mathrm{NaOH}$ ), submitted to $94{ }^{\circ} \mathrm{C}(5 \mathrm{~min})$ and kept on ice until being run on a $170 \mathrm{~mm}$ × $160 \mathrm{~mm}$ × $0.8 \mathrm{~mm}$ polyacrylamide gel (see Table 1 for the electrophoresis conditions used for each allele) and stained with silver nitrate according to the method of Budowle et al. (1991). Putative G390V(F-2) alleles were subsequently confirmed by PCR-RFLP, using the N75 and N73 primers and the HphI restriction enzyme (Nogueira et al., 1992). The digested DNA was subjected to polyacrylamide gel electrophoresis (proportion of bisacrylamide in relation to the total of polyacrylamyde $=3.3 \%$; total concentration of acrylamyde plus bisacrylamyde $=8 \%$ ) and stained with silver nitrate. A control for the $D 70 G(A)$ allele was applied in the gel when necessary.

\section{Statistical analysis}

Frequency distributions, means \pm standard error (SE), the $t$ - test and $\chi^{2}$ test (using Yates' correction when necessary) were calculated using Statistica for Windows (Statsoft, Tulsa, USA).

\section{Results and Discussion}

The enzyme inhibition tests showed two BCHE UA phenotypes in the 145 Kaiowá, one in the 83 Nandeva and none in the 22 Kaiowá-Ñandeva, giving similar D70G $(A)$

Table 1 - Electrophoresis conditions for the amplified products of the human butyrylcholinesterase $B C H E$ gene. The electrophoresis buffer was $1 \mathrm{x}$ tris-borate-EDTA (TBE).

\begin{tabular}{llll}
\hline Conditions & Exon 2 $(D 70 G, G 390 \mathrm{~V})$ & Exon 3 & Exon $4(A 539 T)$ \\
\hline Gel's buffer $^{\prime}$ & $1 \mathrm{x} \mathrm{TBE}$ & Tris-HCl, $\mathrm{pH} 4.6$ & $1 \mathrm{x}$ TBE \\
Acrylamide $^{1}$ & $\mathrm{~T}=9 \% ; \mathrm{C}=3.3 \%$ & $\mathrm{~T}=8 \% ; \mathrm{C}=3.3 \%$ & $\mathrm{~T}=10 \% ; \mathrm{C}=2 \%$ \\
Current and time $^{2}$ & $40 \mathrm{~mA}$ for $4 \mathrm{~h}$ & $10 \mathrm{~mA}$ for $19 \mathrm{~h}$ followed by $2 \mathrm{~h}$ at $240 \mathrm{~V}$ & $40 \mathrm{~mA}$ for $50 \mathrm{~min}$ \\
\hline
\end{tabular}

${ }^{1} \mathrm{~T}=$ total concentration of acrylamyde plus bisacrylamyde in the gel and $\mathrm{C}=$ proportion of bisacrylamide in relation to the total of polyacrylamyde. 
allele frequencies for the Kaiowá $(0.69 \% \pm 0.49 \%)$ and the Ñandeva $(0.60 \% \pm 0.60 \%)$, the overall frequency for this allele being estimated as $0.60 \% \pm 0.35 \%$. A total of 68 individuals (43 Kaiowá, 20 Ñandeva and 5 Kaiowá-Ñandeva) had their DNA examined by PCR-SSCA for the region of the $D 70 G$ mutation and the 3 heterozygotes detected by enzyme inhibition tests were confirmed as having the U/D70G genotype when compared to controls of this genotype.

The degree of non-Amerindian admixture was estimated as $17 \%$ in the Guarani-Ñandeva and 3\% in the Guarani-Kaiowá sub-groups (Tsuneto, 2003) on the basis of the frequency of HLA haplotypes present in Europeans and Africans and only found in Amerindians as due to admixture. Considering the ethnic composition of the 250 Amerindians examined for the $D 70 G$ variant (64\% GuaraniKaiowá and 36\% Guarani-Ñandeva), the respective degrees of admixture of these sub-groups and the frequency of $1.5 \%$ of this variant in Euro-Brazilians (Chautard-Freire-Maia et al., 1984), the expected frequency for the $D 70 G$ variant in this Guarani sample $(0.12 \%)$ due only to European admixture is statistically lower than the one found $\left(\chi^{2}=9.61 ; p<0.01\right)$. African admixture was not considered as a possible source of the $D 70 G$ allele because it has not been found in non-admixed Africans (Whittaker, 1986), pointing to a relatively recent European origin for this allele.

Alcântara et al. (1995) used enzyme inhibition to examine nine Brazilian Amerindian groups and detected the $D 70 G$ allele only in one of these groups, the Mura group from the Guapenu indigenous territory with a frequency of $1.4 \% \pm 1.0 \%$ that does not significantly $\left(\chi^{2}=0.21 ; p>0.60\right)$ differ from the overall frequency for this allele found in the Guarani from Mato Grosso do Sul. Alcântara et al. (1995) revised previous studies on 21 Brazilian Amerindian samples comprising 2,334 individuals in which the $D 70 G$ allele was not found. In other South American Amerindian groups, the $D 70 G$ allele has been found at a frequency ranging from $0.2 \% \pm 0.2 \%$ in the Mataco-Chorote from Argentina (Vergnes and Quilici, 1970) to $3.1 \% \pm 0.6 \%$ in the Makiritare from the Venezuela-Brazil border (Arends et al., 1970). Although the $D 70 G$ allele has also been found in Mexican Amerindians at frequencies of $0.9 \% \pm 0.4 \%$ (Lisker et al., 1964), $0.5 \% \pm 0.1 \%$ (Lisker et al., 1967) and $3.8 \% \pm 1.0 \%$ (Vergnes and Quilici, 1970) it was not found in the only two North-American groups so far studied, the Apache (Lubin et al., 1971) and the Navajo (Garry, 1977). Acuña et al. (2003) reported the $D 70 G$ allele frequencies in the Chilean Mapuche people: $1.1 \% \pm 0.8 \%$ in the Huilliche; $0.9 \% \pm 0.6 \%$ in the Cunco and $0.0 \%$ in the Pehuenche. The present data appear to be the first obtained for Amerindians at the DNA level, and show that the frequency of the $D 70 G$ allele is within the range previously observed in the few Amerindian samples in which it has been found. The absence of this $B C H E$ variant allele in more than 2,300 South
American Amerindians supports the hypothesis that its occurrence in the Guarani from Mato Grosso do Sul is due to gene flow from European populations. The finding that the present frequency of the $D 70 G$ allele in the Guarani is higher than the expected frequency may be explained by random genetic drift.

The genotype and allele frequencies for the $B C H E$ gene and phenotype frequencies for the CHE2 gene are given in Table 2 and the reproductions of polyacrylamide gels showing the amplified DNA products of two segments of exon 2, exon 3 and exon 4 submitted to SSCA are shown in Figure 1.

Since the frequencies of the $G 390 \mathrm{~V}(\mathrm{~F}-2)$ allele in the Guarani-Kaiowá $(9.54 \% \pm 1.82 \%)$ and Guarani-Ñandeva $(7.25 \% \pm 2.21 \%)$ did not differ statistically $\left(\chi^{2}=0.60\right.$, p $>40 \%$ ), an overall frequency for the Guarani can be used $(8.82 \% \pm 1.35 \%)$, including individuals with mixed Guarani origin. The $G 390 \mathrm{~V}$ frequencies previously obtained in our laboratory (Alcântara et al., 1995) based on enzyme inhibition tests of individuals from 13 Brazilian Amerindian groups showed the occurrence of a fluoride resistant allele in only four groups $(7.1 \%$ in the Urubu Kaapor, $2.9 \%$ in the Asurini, $0.7 \%$ in the Mura and $0.5 \%$ in the Sateré-Mawé). Assuming that the fluoride resistant allele in these groups is the $G 390 \mathrm{~V}$ allele, we compared these allelic frequencies with the present $G 390 \mathrm{~V}$ frequency $(8.82 \% \pm 1.35 \%)$, using $\chi^{2}$ tests and found statistically significant differences with: the Asurini $(\mathrm{p}<0.05)$, Mura $(\mathrm{p}=0.001)$ and Sateré-Mawé $(\mathrm{p}<0.0001 \%)$.

The fluoride resistant phenotype presents a wide geographic distribution characterized by low frequencies in non-isolated populations. Concerning the present data, this phenotype was found in $28 \%(5 / 18)$ of the Brazilian Amerindians studied, and relatively high frequencies were observed among groups of the Tupi-Guarani linguistic group (Urubu-Kaapor, Asurini and Guarani from Mato Grosso do Sul) that inhabit very distinct geographic areas. Mikami (2005) examined the DNA of Euro-Brazilians and found the same and very low frequency $(0.28 \% \pm 0.19 \%)$ for each of the $T 243 \mathrm{M}$ and $\mathrm{G} 390 \mathrm{~V}$ fluoride resistant alleles. Considering the ethnic composition (65\% Guarani-Kaiowá and $35 \%$ Guarani-Ñandeva) of the present sub-groups examined for the $G 390 \mathrm{~V}$ allele and the respective degrees of admixture of these sub-groups along with the $0.28 \%$ frequency of this allele in Euro- and Afro-Brazilians (Mikami, 2005), the expected $G 390 \mathrm{~V}$ frequency $(0.022 \%)$ in this Guarani sample due only to admixture is lower statistically $\left(\chi^{2}=15135.52, p<0.0001\right)$ than the frequency found, i.e. less than one expected allele for 39 alleles detected. Taken together, these observations do not seem to support the hypothesis raised in a previous study (Alcântara et al., 1995) that Brazilian Amerindians have received the G390V allele by gene flow from Europeans, although this type of admixture has been detected in the groups presenting this allele. In place of the previous hypothesis, we suggest that 
Table 2 - Genotype and allele frequencies $(\% \pm \mathrm{SE})$ of the human butyrylcholinesterase $B C H E$ gene and phenotype frequencies $(\% \pm \mathrm{SE})$ of the $C H E 2$ gene in Guarani Amerindian sub-groups from the Brazilian state of Mato Grosso do Sul.

\begin{tabular}{|c|c|c|c|c|c|c|}
\hline \multirow{3}{*}{$\begin{array}{l}B C H E \text { genotype } \\
\text { or allele }\end{array}$} & \multicolumn{6}{|c|}{ Guarani Amerindian sub-groups } \\
\hline & \multicolumn{2}{|c|}{ Kaiowá } & \multicolumn{2}{|c|}{ Ñandeva } & \multicolumn{2}{|c|}{ Kaiowá-Ñandeva } \\
\hline & $\mathrm{N}$ & $\% \pm \mathrm{SE}$ & $\mathrm{N}$ & $\% \pm \mathrm{SE}$ & $\mathrm{N}$ & $\% \pm \mathrm{SE}$ \\
\hline \multicolumn{7}{|l|}{ Exon 2} \\
\hline$U / U$ & 106 & $80.92 \pm 3.43$ & 59 & $85.51 \pm 4.24$ & 17 & $80.95 \pm 8.57$ \\
\hline U/G390V & 25 & $19.08 \pm 3.43$ & 10 & $14.49 \pm 4.24$ & 4 & $19.05 \pm 8.57$ \\
\hline G390V & 262 & $9.54 \pm 1.82$ & 138 & $7.25 \pm 2.21$ & 42 & $9.52 \pm 4.53$ \\
\hline \multicolumn{7}{|l|}{ Exon 3} \\
\hline$U / U$ & 149 & $100.00 \pm 0.00$ & 83 & $100.00 \pm 0.00$ & 22 & $100.00 \pm 0.00$ \\
\hline$U$ & 298 & $100.00 \pm 0.00$ & 166 & $100.00 \pm 0.00$ & 44 & $100.00 \pm 0.00$ \\
\hline \multicolumn{7}{|l|}{ Exon 4} \\
\hline$U / U$ & 137 & $93.84 \pm 1.99$ & 70 & $92.11 \pm 3.09$ & 21 & $95.45 \pm 4.44$ \\
\hline U/A539T & 7 & $4.79 \pm 1.77$ & 6 & $7.89 \pm 3.09$ & 1 & $4.55 \pm 4.44$ \\
\hline A539T/A539T & 2 & $1.37 \pm 0.96$ & 0 & $0.00 \pm 0.00$ & 0 & $0.00 \pm 0.00$ \\
\hline$A 539 T$ & 292 & $3.77 \pm 1.11$ & 152 & $3.95 \pm 1.58$ & 44 & $2.27 \pm 2.25$ \\
\hline \multicolumn{7}{|l|}{ CHE2 phenotype } \\
\hline CHE2 C5- & 124 & $85.52 \pm 2.92$ & 68 & $81.93 \pm 4.22$ & 22 & $100.00 \pm 0.00$ \\
\hline CHE2 C5+ & 21 & $14.48 \pm 2.92$ & 15 & $18.07 \pm 4.22$ & 0 & $0.00 \pm 0.00$ \\
\hline
\end{tabular}

$\mathrm{N}=$ number of individuals for genotypes and phenotypes and number of genes for alleles.

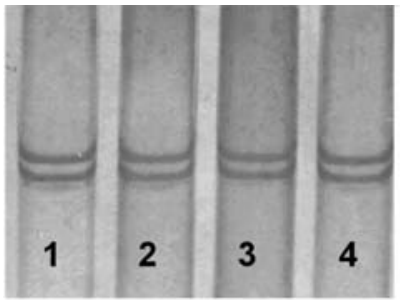

A

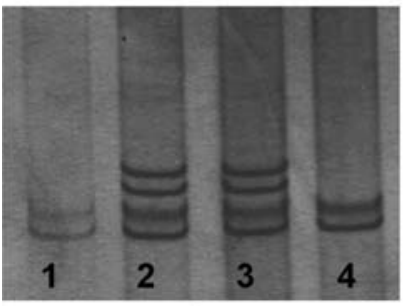

C

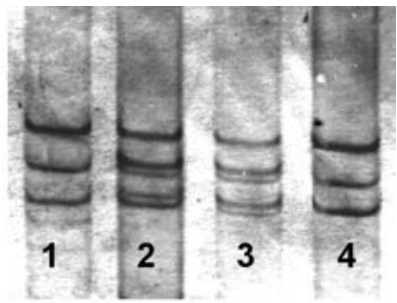

B

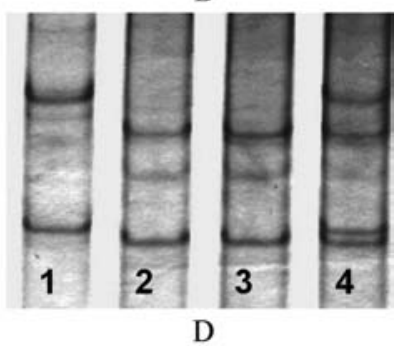

Figure 1 - Polyacrylamide gels showing amplified products of the human butyrylcholinesterase $B C H E$ gene. A: absence of variability in exon 3. B: exon 2 (G390V region) - $U / U(1,4)$; $U / G 390 V(2,3)$. C: exon $2(D 70 G$ region) - U/U (1, 4); U/D70G (2, 3). D: exon 4 - A539T/A539T (1); U/U(2, 3); U/A539T (4).

the $G 390 \mathrm{~V}$ allele was already present in the paleo-Amerindians.

Exon 3 and the flanking regions of introns 2 and 3 (237 pb) did not show molecular variability (Figure 1), owing to the probable idiomorphic character of the mutations already described in this exon and in intron 2: $\mathrm{J}$ (E497V, Bartels et al., 1992a); and four mutations responsible for silent enzymes (IVS2-8T $\rightarrow$ G, Y500X, Q518L - Primo-Parmo et al., 1996; R515C-Maekawa et al., 1995). There is an

approximately $90 \%$ probability of SSCA detecting a variation in a segment of this length (Hayashi and Yandell, 1993), and since we did not use positive controls for these five rare mutations, the absence of variability could be due to the $10 \%$ lack of resolution of SSCA.

Since no significant difference $\left(\chi^{2}=0.01, \mathrm{p}>0.90\right)$ was detected in the frequency of the $A 539 T$ allele at exon 4 in the Guarani-Kaiowá and Guarani-Ñandeva sub-groups, the overall frequency of this allele is $3.69 \% \pm 0.85 \%$, including the total sample of 244 individuals. This was the first time Brazilian Amerindians have been screened for the $A 539 T$ allele, which occurred with a similar frequency to that found by Acuña et al. (2003) in the Chilean Mapuche $\left(5.76 \% \pm 2.29 \% ; \chi^{2}=0.49, \mathrm{p}>0.45\right)$. The frequency of the A539T allele in the Guarani of Mato Grosso do Sul is significantly lower $(\mathrm{p}<0.0001)$ than that found in Euro- Brazilians $\left(18.4 \% \pm 2.8 \%, \chi^{2}=41.19\right)$ and Afro-Brazilians $\left(17.1 \% \pm 2.9 \%, \chi^{2}=33.53\right)$ by Souza et al. (1998) and is also lower ( $\mathrm{p}<0.001$ at least) than in other non-isolated populations already studied, including populations from North America $\left(12.8 \% \pm 3.4 \%, \chi^{2}=11.49\right.$, Bartels et al., 1992b), Japan $\left(16.4 \% \pm 2.4 \%, \chi^{2}=35.31\right.$, Shibuta et al., 1994 and $17.5 \% \pm 2.3 \%, \chi^{2}=42.62$, Izumi et al., 1994), Denmark $\left(18.0 \% \pm 5.4 \%, \chi^{2}=16.60\right.$, Jensen et al., 1996) and Scotland $\left(19.6 \% \pm 3.9 \%, \chi^{2}=35.48\right.$, Gaffney and Campbell, 1994).

The hypothesis of absence of the A539T allele in the ancient South American Amerindians and of its present occurrence due to admixture with individuals of European and African origin was tested using the degree of admixture 
(17\% in the Guarani-Nandeva and 3\% in the Guarani-Kaiowá sub-groups) reported by Tsuneto (2003). Considering that the $A 539 T$ allele frequency is $17.80 \%$ in Euro- and Afro-Brazilians (Souza et al., 1998), the expected frequency due only to admixture for the $A 539 T$ variant in this Guarani sample would be $1.38 \%$ and is statistically lower $\left(\chi^{2}=19.14, \mathrm{p}<0.001\right)$ than the $3.69 \%$ found in the present study. The hypothesis that the $A 539 T$ allele only occurred in Amerindians due to admixture was formulated by Acuña et al. (2003) to explain the frequency of this variant in the Chilean Mapuche but the present data can only be explained by European admixture if it was followed by genetic drift. Considering that the $A 539 T$ allele has a wide ethnical distribution and could also have been present in paleo-Amerindians, an alternative hypothesis is that the low frequency found in this Guarani group in relation to other ethnic groups could be due only to the role played by genetic drift in a small and isolated population.

The frequencies of the CHE2 $\mathrm{C} 5+$ phenotype was $14.48 \% \pm 2.92 \%$ in the Guarani-Kaiowá and $18.07 \% \pm 4.22 \%$ in the Guarani-Ñandeva sub-groups (Table 2$)$ and did not differ statistically $\left(\chi^{2}=0.51, p>45 \%\right)$, indicating that these sub-groups can be considered as one population sample in relation to $C H E 2$ gene variability with the overall CHE2 C5+ frequency in the 250 examined individuals being $14.40 \% \pm 2.22 \%$ (not shown in Table 2 ). The CHE2 C5+ phenotype has been found in many other Amerindian populations (Primo-Parmo et al., 1986; Guerreiro et al., 1987; Alcântara et al., 1995), indicating a wide distribution among Brazilian Amerindians from what was inferred the occurrence of the $\mathrm{CHE} 2 * \mathrm{C} 5+$ allele in the paleo-Amerindians. Alcântara et al. (1995) have reported that the Guarani-M'byá sub-group from Rio das Cobras, in the Brazilian state of Paraná, has a CHE2 C5+ frequency of $45.93 \% \pm 3.80 \%$ and when this was compared with the present data $(14.40 \% \pm 2.22 \%)$, a statistically significant difference was found $\left(\chi^{2}=51.10 ; \mathrm{p}<0.0001 \%\right)$. The present data on CHE2 C5+ phenotype frequencies are in the same direction as data previously obtained on the basis of $H L A-D R B 1$ allele frequencies which led to estimates of genetic distances between the M'byá and Kaiowá (0.0410), M'byá and Ñandeva (0.0307) and Kaiowá and Nandeva (0.0165) (Tsuneto et al., 2003; Petzl-Erler, 2005, pers. comm.). Considering the CHE2 C5+ present data and the frequency distribution of this phenotype in the 29 different samples of Brazilian Amerindian populations studied by Alcântara et al. (1995) in which the frequency of this phenotype ranged from 0 to $50.5 \%$ without showing any gradient, it seems that genetic drift is the main evolutionary factor responsible for the $\mathrm{CHE} 2$ variability distribution in these Amerindian groups. This may also be the reason for the difference shown by the Guarani sub-groups from quite different Brazilian geographic areas. As far as we can ascertain from the available data, natural selection does not seem to have played any relevant role in the present distri- bution of CHE2 C5+ frequencies in the Brazilian Amerindians so far studied.

The mean BChE activity of the Kaiowá sample $(\mathrm{N}=49 ; 3.89 \pm 0.20 \mathrm{KU} / \mathrm{L})$ and of the Nandeva sample $(\mathrm{N}=27 ; 4.28 \pm 0.29 \mathrm{KU} / \mathrm{L})$ do not differ $(t=1.13)$. The overall mean BChE activity was $4.01 \pm 0.15 \mathrm{KU} / \mathrm{L}$ for 86 individuals, including mixed descendants from the two groups. This overall mean was significantly higher $(\mathrm{p}<0.001)$ than the mean values reported for 189 individuals from the Pacaás Novos $(2.5 \pm 0.07 \mathrm{KU} / \mathrm{L}, t=9.12), 193$ individuals from the Sateré Mawé $(3.0 \pm 0.08 \mathrm{KU} / \mathrm{L}$, $t=5.82)$ and 23 individuals from the Tenharim $(2.9 \pm 0.1$ $\mathrm{KU} / \mathrm{L}, t=6.10$ ), all Brazilian Amerindian groups studied by Primo-Parmo et al. (1986). The differences found in these mean activities may be due to differences in eating habits, BChE variant frequencies and plasma storage time.

A well known fact documented by many studies is that Amerindians show less genetic variability than nonisolated populations. The $B C H E$ gene variability found in present study in the Guarani sub-groups differs from that found in non-isolated populations in terms of the frequencies of the $G 390 \mathrm{~V}$ and $A 539 T$ alleles. When the total heterozygote frequency (24.6\%: $U / D 70 G=1.20 \%$; $U / G 390 \mathrm{~V}=17.65 \%$; U/A539T $=5.74 \%$ ) found for the $B C H E$ gene in the present study was compared to the respective expected (33.4\%: U/A539T $=29.26 \%$ - Souza et al., 1998; $U / D 70 G=3.53 \%$ and $U / G 390 \mathrm{~V}=0.56 \%$ Mikami, 2005) for the general population of Curitiba (South Brazil) it was shown that the Guarani presented significantly lower heterozygote frequency $\left(\chi^{2}=8.00\right.$; $\mathrm{p}<0.01)$ on what refers to these variants considered for the $B C H E$ gene.

\section{Acknowledgements}

We are grateful for the grants received from Conselho Nacional de Desenvolvimento Científico e Tecnológico (CNPq), Coordenação de Aperfeiçoamento de Pessoal de Nível Superior (CAPES) and Fundação da Universidade Federal do Paraná. Researchers received scholarships from CNPq and CAPES.

\section{References}

Acuña ML, Eaton NR, Ramírez NR, Cifuentes L and Llop E (2003) Genetic variants of serum butyrylcholinesterase in Chilean Mapuche Indians. Am J Phys Anthrop 121:81-85.

Alcântara VM, Chautard-Freire-Maia EA, Pichet G and Vieira MM (1991) A method for serum cholinesterase phenotyping. Rev Brasil Genet 14:841-846.

Alcântara VM, Lourenço MAC, Salzano FM, Petzl-Erler ML, Coimbra Jr CEA, Santos RV and Chautard-Freire-Maia EA (1995) Butyrylcholinesterase polymorphisms (BCHE_and CHE2 loci) in Brazilian Indian and admixed populations. Hum Biol 67:717-726.

Alcântara VM, Rodrigues LC, Oliveira LC and Chautard-FreireMaia EA (2001) Association of the CHE2 locus with body 
mass index and butyrylcholinesterase activity. Hum Biol 73:587-595

Arends T, Weitkamp LR, Gallango ML, Neel JW and Schultz J (1970) Gene frequencies and micro-differentiation among the Makiritare Indians. Am J Hum Genet 22:526-532.

Arpagaus M, Kott M, Vatsis KP, Bartels CF, La Du BN and Lockridge O (1990) Structure of the gene for human butyrylcholinesterase. Evidence for a single copy. Biochem 29:124-131.

Bartels CF, James K and La Du BN (1992a) DNA mutations associated with the human butyrylcholinesterase J-variant. Am J Hum Genet 50:1104-1114.

Bartels CF, Jensen FS, Lockridge O, van der Spek AFL, Rubinstein HM, Lubrano T and La Du BN (1992b) DNA mutation associated with the human butyrylcholinesterase K-variant and its linkage to the atypical variant mutation and other polymorphic sites. Am J Hum Genet 50:1086-1103.

Budowle B, Chakraborty R, Giusti AM, Eisenberg AJ and Allen RE (1991) Analysis of the VNTR locus DIS 80 by the PCR followed by high-resolution PAGE. Am J Hum Genet 48:137-144.

Chautard-Freire-Maia EA, Primo-Parmo SL, Lourenço MAC and Culpi L (1984) Frequencies of atypical serum cholinesterase among Caucasians and Negroes from Southern Brazil. Hum Hered 34:388-392.

Dietz AA, Rubinstein HM and Lubrano T (1973) Colorimetric determination of serum cholinesterase and its genetic variants by the propionylthiocholine-dithiobis (nitrobenzoic acid) procedure. Clin Chem 19:1309-1313.

Gaffney D and Campbell RA (1994) A PCR based method to determine the Kalow allele of the cholinesterase gene: The $\mathrm{E}_{1}^{\mathrm{k}}$ allele frequency and its significance in the normal population. J Med Genet 31:248-250.

Garry PJ (1977) Atypical $\left(\mathrm{E}_{1}^{\mathrm{a}}\right)$ and fluoride resistant $\left(\mathrm{E}_{1}{ }^{\mathrm{f}}\right)$ cholinesterase genes: Absent in a native American Indian population. Hum Hered 27:433-436.

Guerreiro JF, Santos SEB, Lourenço MAC, Primo-Parmo SL and Chautard-Freire-Maia EA (1987) Serum cholinesterase polymorphism (CHE1 and CHE2 loci) in Indians from the Amazon region of Brazil: Urubu-Kaapor and Assurini groups. Rev Bras Genet 10:781-785.

Hayashi K and Yandell DW (1993) How sensitive is PCR-SSCP? Hum Mutat 2:338-346.

Höhler T, Hundt M, Rittner C, Schneider PM and Büschenfelde KHM (1995) Cholinesterase variants: Rapid characterization by PCR/SSCP and evidence for molecular homogeneity. J Med Genet 32:109-112.

Izumi M, Maekawa M and Kanno T (1994) Butyrylcholinesterase $\mathrm{K}$-variant in Japan: Frequency of allele and associated enzyme activity in serum. Clin Chem 40:1606-1607.

Jensen FS, Nielsen LR and Schwartz M (1996) Detection of plasma cholinesterase $\mathrm{K}$ variant by PCR using an amplification-created restriction site. Hum Hered 46:26-31.

Lahiri DK and Nurnberger Jr JI (1991) A rapid non-enzymatic method for the preparation of HMW DNA from blood for RFLP studies. Nucl Acids Res 19:5444.

Lisker R, Moral C and Loría A (1964) Frequency of the atypical pseudocholinesterase in four Indian (Mexican) groups. Nature 202:815

Lisker R, Zárate G and Rodríguez E (1967) Studies on several genetic hematological traits of the Mexican population. XVI. Serum polymorphisms in several Indian groups. Am J Phys Anthropol 27:27-32.
Lubin AH, Garry PJ and Owen GM (1971) Sex and population differences in the incidence of a plasma cholinesterase variant. Science 173:161-164.

Maekawa M, Sudo K, Kanno T, Kotani K, Dey DC, Ishikawa J, Izume M and Etoh K (1995) Genetic basis of the silent phenotype of serum butyrylcholinesterase in three compound heterozygotes. Clin Chim Acta 235:41-57.

Masson P (1991) Molecular heterogeneity of human plasma cholinesterase. In: Massoulié J, Bacou F, Barnard E, Chatonnet A, Doctor BP and Quinn DM (eds) Cholinesterases. Structure, Function, Mechanisms, Genetics and Cell Biology. American Chemical Society, Washington D.C, pp 42-45.

Mikami LR (2005) Variabilidade dos exons 2 e 4 do gene $B C H E$ e sua relação com a atividade da butirilcolinesterase. $\mathrm{PhD}$ Thesis, Universidade Federal do Paraná, Curitiba.

Nogueira CP, Bartels CF, Mcguire MC, Adkins S, Lubrano T, Rubinstein HM, Lightstone H, van der Spek AFL, Lockridge O and La Du BN (1992) Identification of two different point mutations associated with the fluoride-resistant phenotype for human butyrylcholinesterase. Am J Hum Genet 51:821-828.

Picheth G, Fadel-Picheth C, Primo-Parmo SL, Chautard-FreireMaia EA and Vieira MM (1994) An improved method for butyrylcholinesterase phenotyping. Biochem Genet 32:8389.

Primo-Parmo SL, Bartels CF, Wiersema B, van der Spek AFL, Innis JW and La Du BN (1996) Characterization of 12 silent alleles of the human butyrylcholinesterase (BCHE) gene. Am J Hum Genet 58:52-64.

Primo-Parmo SL, Chautard-Freire-Maia EA, Lourenço MAC, Salzano FM and Freitas MJM (1986) Studies on serum cholinesterase (CHE1 and CHE2) in Brazilian Indian and admixed populations. Rev Bras Genet 9:467-478.

Shibuta K, Abe M and Suzuki T (1994) A new detection method for the $\mathrm{K}$ variant of butyrylcholinesterase based on PCR primer introduced restriction analysis (PCR-PIRA). J Med Genet 31:576-579.

Souza RLR, Castro RMV, Pereira L, Freund AA, Culpi L and Chautard-Freire-Maia EA (1998) Frequencies of the butyrylcholinesterase $\mathrm{K}$ mutation in Brazilian populations of European and African origin. Hum Biol 70:965-970.

Souza RLR, Fadel-Picheth C, Allebrandt KV, Furtado L and Chautard-Freire-Maia EA (2005) Possible influence of the $B C H E$ locus of butyrylcholinesterase on stature and body mass index. Am J Phys Anthropol 126:329-334.

Tsuneto LT (2003) Polimorfismo HLA em cinco populações ameríndias. PhD Thesis, Universidade Federal do Paraná, Curitiba.

Tsuneto LT, Probst CM, Hutz MH, Salzano FM, RodriguezDelfin LA, Zago MA, Hill K, Hurtado AM, Ribeiro-dosSantos AKC and Petzl-Erler ML (2003) HLA class II in seven Amerindian populations. Clues about the origins of the Aché. Tissue Antigens 62:512-526.

Van Ros G and Vervoort T (1973) Frequencies of the 'atypical' and $\mathrm{C}_{5}$ variants of serum cholinesterase in Zairians and Belgians. Detection of the $\mathrm{C}_{5}$ variant by agar gel electrophoresis with an acid buffer. Ann Soc Belge Méd Trop 53:633-644.

Vergnes H and Quilici JC (1970) Le gene $\mathrm{E}_{1}{ }^{\mathrm{a}}$ de la pseudocholinestérase sérique (A.C.A.H.) chez les Amérindiens. Ann Genet 13:96-99.

Whittaker M (1986) Cholinesterase. Karger, Basel, pp 51. Associate Editor: Francisco Mauro Salzano 